\title{
WARM COLORS, THE ENCOURAGEMENT
}

\author{
Mita Purbasari* \\ Visual Communication Design, Binus Northumbria School of Design, Bina Nusantara University \\ Jl. K. H. Syahdan No. 9, Kemanggisan, Palmerah, Jakarta 11480, Indonesia \\ mitawahid@binus.edu
}

Received: $25^{\text {th }}$ January 2021/ Revised: $01^{\text {st }}$ March 2021/ Accepted: $02^{\text {nd }}$ March 2021

How to Cite: Purbasari, M. (2021). Warm colors, the encouragement. Humaniora, 12(1), 61-67.

https://doi.org/10.21512/humaniora.v12i1.6973

\begin{abstract}
The research discussed the warm colors, such as yellow, orange, and red, as individual colors with a composition that could have a different impact on color connoisseurs depending on the background and context. The color was one design element that was rarely noticed but often used in everyday life. Color adds not only the beauty of an object but also the ability to manipulate the eyes and mind, often used to communicate without words. Using the right color at the right time and place could quickly send a message that was both fun and sad. The same color could mean different things in different cultural, social, economic, and political settings. Different cultures endowed color with different meanings depending on many things. As for color users, it was good to understand the effects of colors that were likely to occur to minimize the negative things. The research method applied was a qualitative narrative by collecting data from the literature, interviewing users and connoisseurs of color, observing, and analyzed. It is found that warm colors are often interpreted as bad things for some people in Jakarta, but they can also become symbols of courage and passion. It is hoped that these research results can be used as a rationale for making design work.
\end{abstract}

Keywords: warm colors, cultural meanings, encouragement symbol

\section{INTRODUCTION}

Color is the fastest method of delivering messages and meanings in the category of non-verbal communication (Rossi et al., 2018). Color can be very effective for use in quickly identifying and clarifying complex information. Colors are readable faster than shapes (Green-Armytage, 2017). Color is an essential part of an art worker. However, in everyday life, because humans use colors in daily life, the color becomes common. That is why color research is rare. This is because this design element is more digested and processed by feelings, not thoughts so that colors are often seen as something that is not important.

Since ancient times, before humans learned to appreciate the beauty of color, they have a more practical way of communicating with color. As the sky grows darker, it turns sky to gray or black, and humans have predicted that rain would fall on the earth. Furthermore, if there is a roar in the sky, there will be lightning. When the people of Jakarta (Betawi) see the yellow flag, it means that there must be grief not far from the location of the flag (Purbasari, Marianto, \& Burhan, 2016). This indicates that the color has been used as a sign in everyday life.

In visual messages, color adds extraordinary meaning in conveying the message. Color has different meanings in many ways, referring to different cultures and people (Sevinc \& Osueke, 2014). Everyone has their own favorite color, just as everyone has their favorite food (Purbasari \& Jakti, 2014). Cultural identity is a social construction and can be expressed through various forms of representation that can be recognized by others (universal). Therefore, the use of the same color can function and have different meanings in different places, times, and conditions (Elliot, 2015).

The color circle is the easiest color guide to use. In the Visual Communication Design world, the color circle of Johannes Itten based on the Bauhaus school of design is fundamental to color theory. The basic color circle is divided into three, called primary (the basic 
color), secondary (mixing two primary colors), and tertiary (mixing primary and secondary colors). The primary colors are yellow, red, and blue. Secondary colors are orange that comes from a mixture of yellow and red; purple comes from a mixture of red and blue; the last one is green that comes from yellow and blue. A tertiary color is a mixture of one primary color and one secondary color. The colors are yellow-orange, orange-red, red-purple, purple-blue, blue-green, and green-yellow. Generally, color temperature refers to how 'warm' or 'cool' a color (Scoot, 2018). Warm colors range from yellow to red-purple, associated with warmth, anger, courage, spiciness, and danger. Whereas cool colors range from purple to greenyellow, which represent coolness, the ocean, the sky, outer space, and leaves. It can be seen in Figure 1.

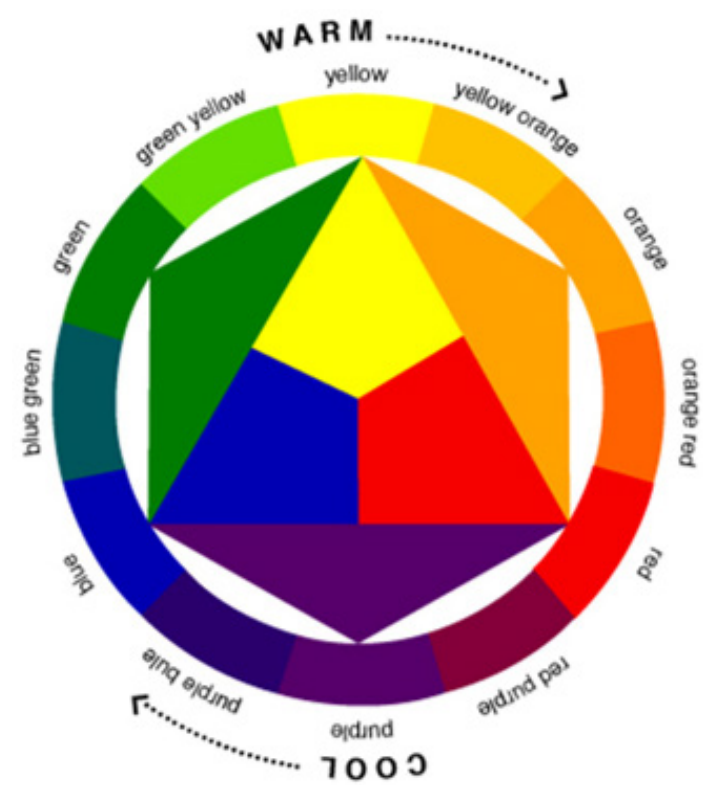

Figure 1 Color Temperature in Itten's Wheels (Recreated by Purbasari, 2021)

The combination of warm colors has a high level of color intensity so that it quickly tires the eyes. Often create an energetic, active, dynamic impression where these colors are often used to demand attention. As stated above, each color has a different meaning and psychological aspect for each user. By using literature research and visual examples, it is hoped that color users can make good use of color according to their goals and targets so that messages can be conveyed quickly.

\section{METHODS}

The research applies a descriptive qualitative method of data literature and documentation of related objects. The interview is done with color users (graphic designer, fashion designer, interior designer, and psychologist). The results of the interviews are used to prove the color theories circulating in society.
The research was conducted in Jakarta for one year in 2019.

The research process carried out is (1) literature data collection, (2) documenting drawings according to the warm color category (family of red, orange, and yellow), (3) color user interviews, and (4) deep observation and analysis by using Charles Morris semiotics approach. Semiotics is the study of meaning-creating, sign processes, and meaningful communication (Hoed, 2011). Semiotics focuses on syntactic (the relationship between a sign and another), semantics (the relationship between a sign and its basic meaning), and pragmatic (the relationship between a sign and its users) (Danesi, 2004). In the research, syntactic is the relationship between color and the objects, semantics is the relationship between color and its meaning, while pragmatic is the relationship between colors and humans.

\section{RESULTS AND DISCUSSIONS}

The colors that people see whenever waking up in the morning and starting the activities until they close their eyes to get some rest at night are highly affecting their lives and feelings (Sevinc \& Osueke, 2014). As explained, every human being has different experiences with color. Many factors influence how humans receive and how they receive color feedback itself. The color yellow for many cultures is closely associated with relationships with the universe, such as the sun (energetic), great (worship of the Almighty), optimism, and joy (Smith, 2019b). For example, Javanese people associate yellow as a color representing nobility, glory, prosperity, and tranquility (Lampu Edison, 2020). Therefore, many old houses in Yogyakarta, especially around the Kraton, paint their walls yellow as a representative of the gold color (Figure 2). It is hoped that this house will get many blessings, be prosperous, and safe for its residents.

Each culture has a unique heritage of color symbolism, which represents its culture. As living creatures that usually move from one place to another, humans must carry their cultural colors and try hard to adapt and blend in with new environments. Broadly speaking, certain cultures will have the same reaction to certain colors as well (Pettersson, 1982). For example, in Betawi culture, red often appears together with other bright colors. The red in a Betawi wedding dress has a cultural influence from China called Hong means a sacred color (Figure 3). It has a very positive meaning, and it is believed to give good energy, a source of joy, courage, luck, fortitude, and luxury (Woelandhary, 2019).

To describe and explain in an easy way, these warm colors studied will be equipped with examples of colors and objects directly related to these colors. The first is yellow. The yellow color has a color arrangement from light yellow to dark and from greenish-yellow to orange-yellow. Gradation yellow to black will cause a dark greenish-yellow color, while 
gradations to white make the yellow paler, lighter, and quickly approach white. This restriction is based on Itten's color circle. According to pantone.com, yellow is one of the trend colors for 2021, with the names Illuminating (yellow) and Ultimate Gray (gray). It can be seen in Figure 4.

Yellow is the primary color that is often placed at the top of the color wheel, also in Itten's color wheel. Apart from having the highest light intensity, yellow is often connoted with sun, light, warmth, something great (associated with the creator), prosperity (associated with gold), and joy.

A Betawi writer from the Betawi Cultural Institute, Yahya Andi Saputra, has said that the yellow color in Betawi is influenced by Malay, which means the greatness of the ruler of nature, God Almighty. That is why many Betawi homes have yellow walls and fences, as a form of respect for the Creator and the hope of the inhabitants of the house to be protected from all troubles (Purbasari, Marianto, \& Burhan, 2016). Malays consider yellow a symbol of purity. The yellow color for the ancient Malay kingdoms that once triumphed in the archipelago is a sacred color because it could only be used by the royal court or the royal family. Other parts of Indonesia that are close to Malay culture, such as the Minangkabau people, view yellow as a color that has greatness and justice (Lampu Edison, 2020). Based on the focus group discussion,
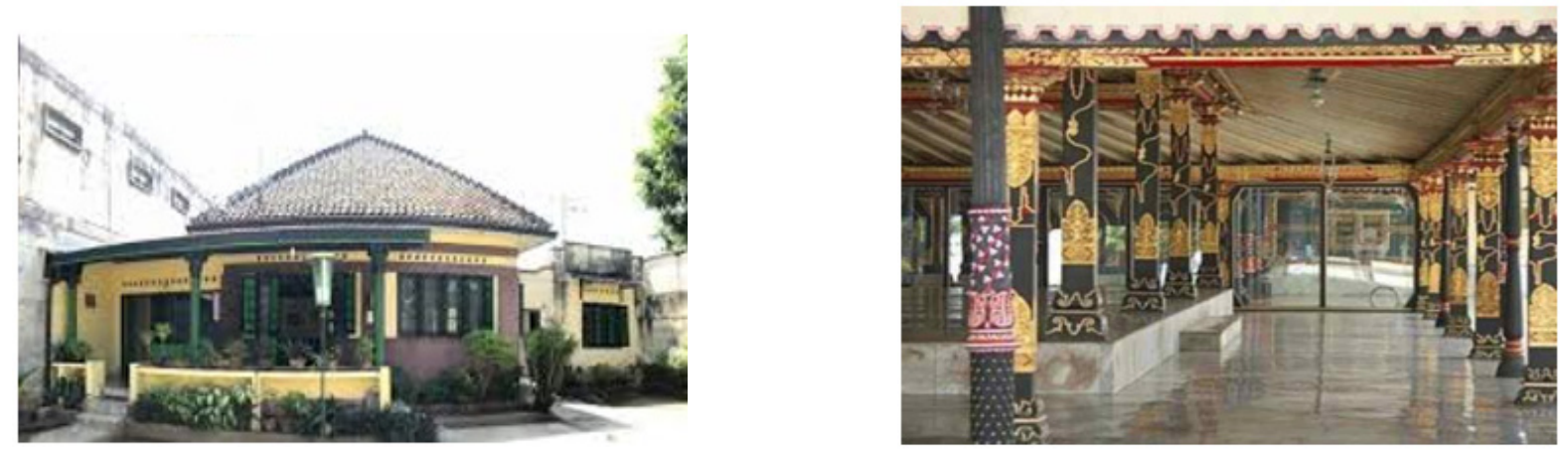

Figure 2 Houses and Kraton in Yogyakarta

(Lamudi.co.id, 2020)

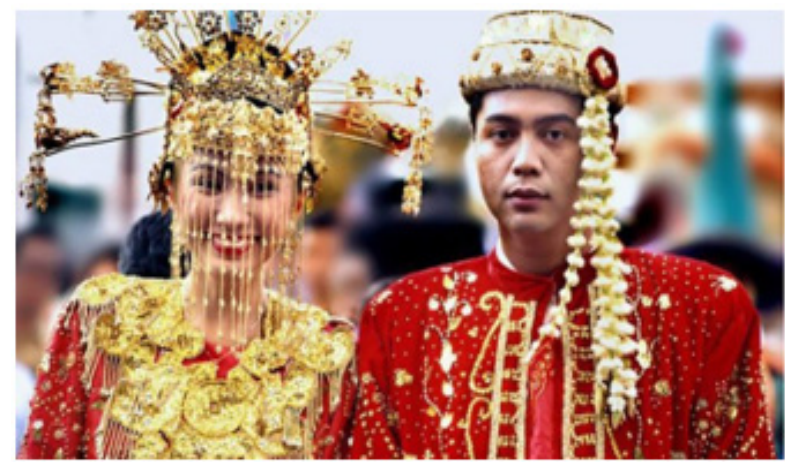

Figure 3 Betawi Wedding Dress

(Rumahulin, 2019)

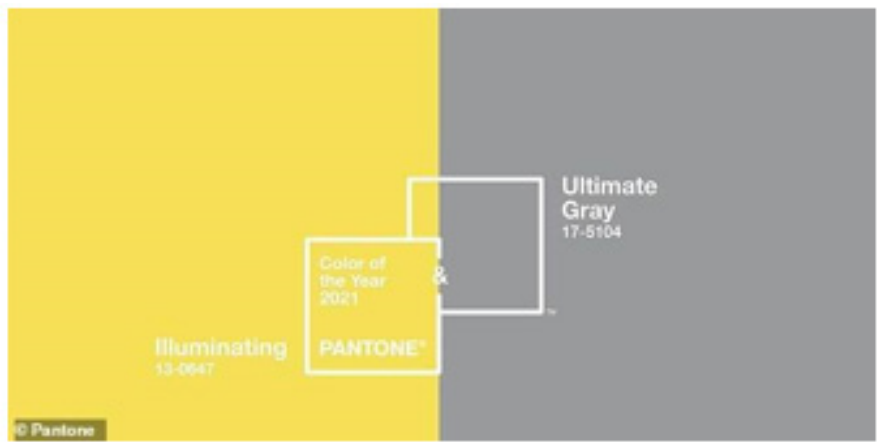

Figure 4 Color of 2021

(Pantone.com) 
four resource persons said that yellow is an attractive color that creating a festive atmosphere. Not everyone is able to take control when using yellow. Therefore, the wrong combination of yellow will create fatigue, headache, and cause disgust.

In general, yellow quickly becomes associated with sun and joy. In everyday life, yellow is often used in food and beverage packaging because it has a lot to do with cooking spices and fruits. Therefore, yellow is also used as an appetite color. The food and drink that colored yellow can make people drool because it provokes a sour taste which then creates hunger. Using too much yellow can distract from the focus because it is the color with the highest intensity level. Usually, yellow will be balanced with neutral colors, dark, and analog colors depending on its purpose. In previous studies, it is mentioned that several color names associated with yellow are obtained from animals, fruits, and flowers. The examples are yellow tusk, yellow canary, lemon, honey, mustard, buttercup, blonde, yellow egg, mango, etcetera (Figure 5).

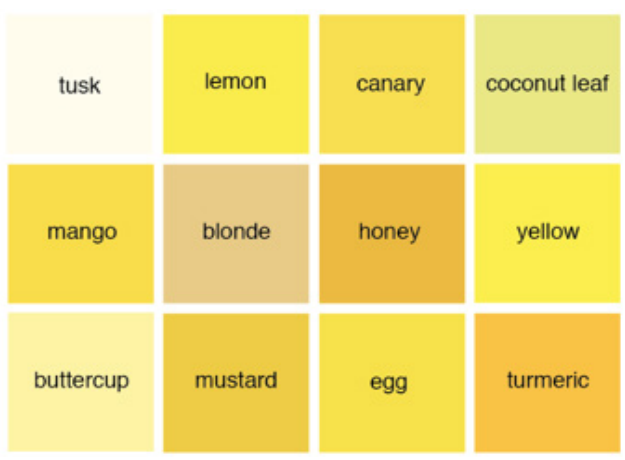

Figure 5 Example of Yellow Family Colors (Created by Purbasari, 2021)

The next one is orange. The orange colors discussed here include yellowish orange, orange, and reddish-orange. This restriction is adjusted to the colors in the color circle. A gradient from orange to white creates a new lighter color, like peach and salmon, while a black gradient makes it darker, like brown. A family of orange color has been the color of choice for Pantone in the past years, such as living coral (2019), tangerine (2012), and tigerlily (2004), as shown in Figure 6.

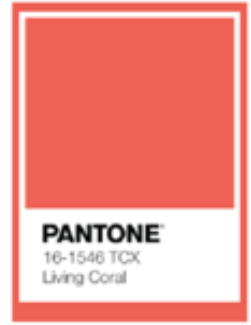

2019

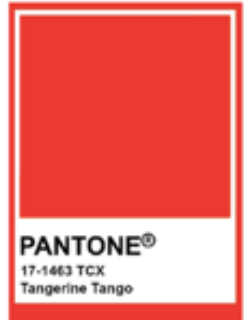

2012

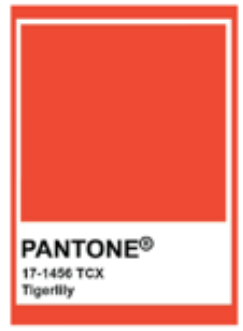

2004
Figure 6 Past Orange Family Colors of The Year (Pantone.com)
Orange is a secondary color obtained from mixing two primary colors, yellow and red. Orange is often associated with energy, high spirits, and a dynamic social environment (Smith, 2019a). Orange is mostly found in fruits, flowers, and natural landscapes because this color is closely related to the sun in the afternoon. Even though it does not have a light intensity as high as yellow, this color looks attractive because it has yellow and red characters. Also, orange able to increase appetite with sour and sweet taste as well.

In western countries, orange is a dynamic, refreshing, fun, and friendly color. The word orange is taken from the name of a fruit that is full of vitamin $\mathrm{C}$, juicy and healthy, called orange. It is one of the active colors that can increase emotions, activity, and sharpen awareness of the social environment. Orange is also synonymous with the color of a large pumpkin, which later becomes one of the colors for Halloween events. Orange is also a color that is not recommended to be overused because it tends to strike and tire the eyes (Morton, 2021a).

In Indonesia, orange was the color trend in 2002-2004. Several banks in Indonesia use the orange color of their new logo, such as BNI 46 and Danamon. BNI 46 uses orange as a symbol of modernity, fun, and friendship. Meanwhile, Bank Danamon uses orange as a symbol of confidence, courage to be different, and strong (the standout character of orange) (Leo, 2019). In Indonesian culture, orange is rarely used, most likely because it is more often seen as red. For example, the color of tile or brick is often referred to as brick red or tile red. Not many names for the color orange are used in Indonesia. Based on research on color names that have been done, only the words temaram (twilight) and oranges are connotated to the color orange (Purbasari \& Jakti, 2011).

The color orange is used in Jakarta as part of the popular culture of the Betawi people. Oren (how Betawi called orange color) becomes a Jakarta icon color. During a football game of Persija (Jakarta Indonesia Football Association), orange is used as an obliged attribute by Persija supporters known as The Jack Mania. Oren is also used by buses or typical Jakarta public transportation, such as metro mini. In other words, in Betawi culture, orange is used as a distinctive contemporary color (Purbasari, Marianto, \& Burhan, 2016). According to the focus group discussion of a four-color user in different fields, orange is a very attractive and rich color because it comes from two bright primary colors. Not too many people like orange because it has a high-level intensity, bright, bold, and seems noisy. No wonder Jakarta has orange as a contemporary identity color.

In previous research, it is mentioned that several color names related to orange are mostly obtained from natural objects, fruits, and flowers. The examples are orange, twilight, tabasco, papaya, persimmon, pumpkin, salmon, melon, and others (Figure 7).

Many color names refer to the orange but are categorized as red, such as red faces like boiled shrimp 
or orange fish, often called goldfish. Because the color has a clear and high level of information, orange is widely used for street workers and street clans because it is used to set objects apart from their surroundings, particularly in complementary contrast to the azure color of the sky and the tree (Figure 8). In addition, in some countries, orange is used as a uniform for prisoners so that they can be easily seen and found if they escape or escape from prison.

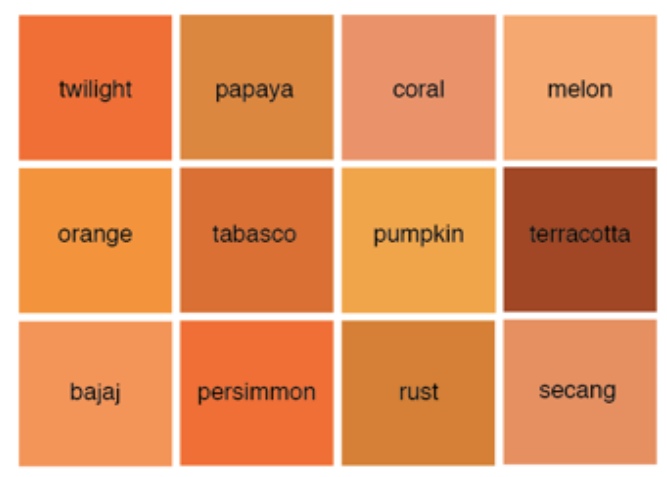

Figure 7 Examples of Orange Family Colors (Created by Purbasari, 2021)

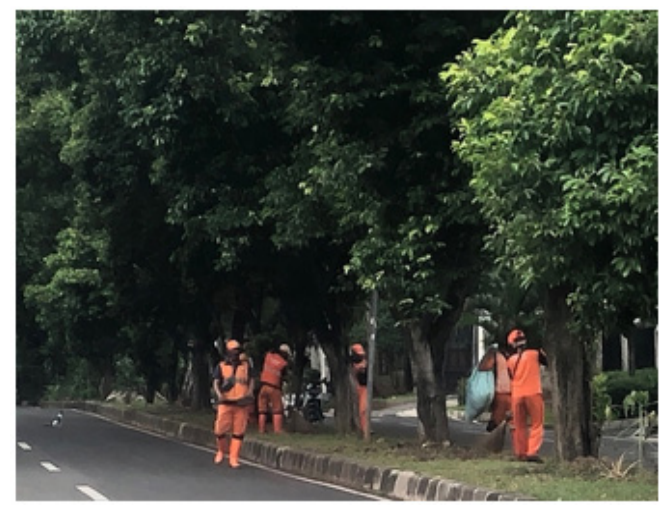

Figure 8 Orange for Street Workers Uniform (Purbasari, 2021)

The next color that will be discussed is red. The red color in this discussion includes yellowish red (orange-red), red, purplish-red. This restriction is adjusted to the colors in Johannes Itten's color circle. Gradations of red to white make them look younger, childish, sweet, such as pink, fuchsia, and rose, while gradations to black make them darker, such as maroon, scarlet, mahogany, and so on. Red is the most popular color, along with blue (Morton, 2021b). Family of red color has been the color of the year in past years, such as rose quartz (2016), honeysuckle (2011), chili pepper (2007), true red (2002), and fuchsia rose (2001), as shown in Figure 9. Besides, the red color has a very striking and attractive color character. Many objects in the universe are red, making the human eye gets used to seeing and dealing with the red family. This proves that the red color family is often seen, used, and liked by a human.

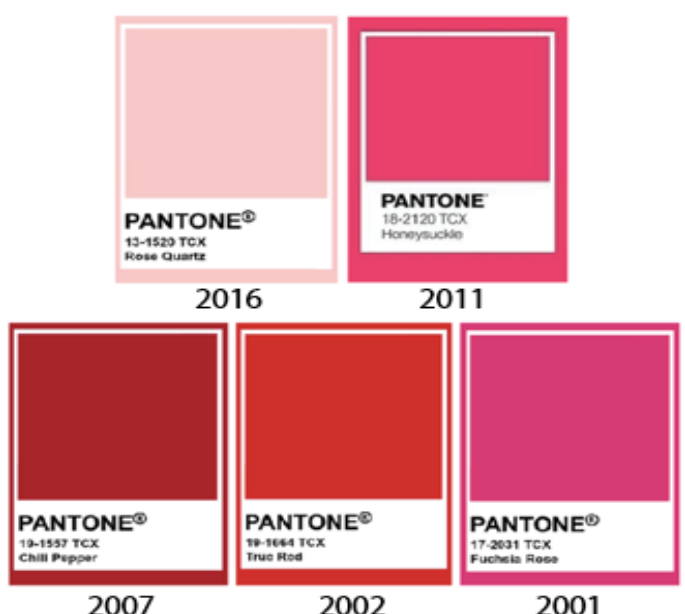

Figure 9 Past Red Family Colors of the Year (Pantone.com)

Red is one of the primary colors in Johannes Itten's color circle besides yellow and blue. Just like yellow and blue, red also has many positive and negative qualities. The color red is an intense color packed with emotions ranging from passion, passionate love, anger, and violence. Red is often associated with high emotions and temperament. The visualization of a person's face in red is always associated with emotions, such as anger, shame, fatigue, and others. An evil creature with a scary face is often visualized in red. The red color is often found in natural objects such as ripe fruits, flowers, and natural stones. Red is an extreme color that has two opposing sides. One represents passionate, seductive love, burning desire, but on the other hand, it means anger, danger, violence, blood, hard struggle (Morton, 2021b). Many people express love with red roses, write letters of protest and anger in red ink. It indicates that red is capable of having two opposing characters, love and hate at the same time.

In everyday life, the color red is often associated with blood and fire (Kuniecki, Pilarczyk, \& Wichary, 2015). Blood is a giver of life and fire as encouragement. Like orange, red is also a color that can enhance appetite (Piqueras-Fiszman \& Spence, 2014), respiratory rhythm, and blood pressure. Red is often using in food and its packaging as a lure for buyers because it can attract attention and persuade people to buy it. A syrup with a red tone is more seductive than a syrup with a green color.

It is common knowledge that red is the lucky color for people in Asia (Kumar, 2016), especially in China. The Japanese flag has a red circle symbolizing the sun. In some countries, red is a lucky color in marriage, such as in Nepal and India by wearing a red Sari dress, in Japan using a red Kimono, in China using a red Qipao dress, Mongolia using a red Deel dress, Korea wearing a red Hanbok dress, Betawi (Jakarta) with the red Care Haji dress up, and Care None bride Cine dress up as shown in Figure 3. This red color is a symbol of happiness, hope, and luck. It is the same 
in Chinese culture, where the red color at a wedding ceremony means good luck, prosperity, happiness, and long life to everyone (Widyaningrum, 2019). Red is the strongest color of all colors in Indian culture and has many important meanings compared to other colors. Red means fear, fire, wealth, strength, purity, fertility, temptation, love, and beauty. The red color is also representative of a personal life. In Thailand tradition, red is the color for Sundays, associated with the Sun God who was born on that day.

Within Indonesian culture, the red color has a lot of different meanings. Besides, red means courage, as it is often known in the national flag; red also means different things in each region in Indonesia, depending on the context. In the independence era, red was interpreted as courage because of the context, where the Indonesians were fighting to the death against colonialism. However, over time, the fight for life in a physical form is replaced by others, such as fighting poverty, hunger, illiteracy, pandemics, and so on, so it may be that the colors used will also be different. The meaning of red changes according to the demands of the era. When the economy starts to improve, people's purchasing power improves, education is included in the development priorities of a country, and tourism is the main focus; the red color is widely used in the business world. For example, it is used as the logo for fast food places, banking logos, food and beverage packaging with strawberry, watermelon, spicy (chili) flavors.

In Betawi culture, the red color is one of the eight distinctive Betawi colors interpreted as festivity, courage, and respect. Apart from being strongly influenced by Chinese and Hindu culture, the Betawi people often use red in all cultural activities. Syrup and sugar palm fruit, the color of Marjan, are usually served to guests when visiting someone's house, especially during the month of Ramadhan and Eid Mubarak in the Betawi community. Serving this snack is a sign of honor to guests (Purbasari, Marianto, \& Burhan, 2016). Besides, the face of the male ondelondel (traditional doll) is red, a symbol of courage and assertiveness in expelling and protecting the Betawi people from harm. In Betawi art performances, the red color is used as an invitation and an addition to the festivities (Wahidiyat \& Tabroni, 2020).

Focus group discussion of the four-color user mentioned that red is one of classic color, long-lasting color, very sexy, and dangerous at one time, and no one can refuse red. Red is a perfect color to use. As a primary color, many people recognize red quickly, and it is good to get people's attention the right way. In previous color research, it is mentioned that several color names that are local, universal, and related to red are mostly obtained from natural or natural objects, fruits, and flowers. Examples of it are blood red, ruby red, roasted red, crimson red, red district, red thread, red lipstick. There are various types of red in western countries, such as maroon, burgundy, crimson, scarlet, magenta, fuchsia, rose, peach, and so on. Figure 10 shows the examples of red family color.

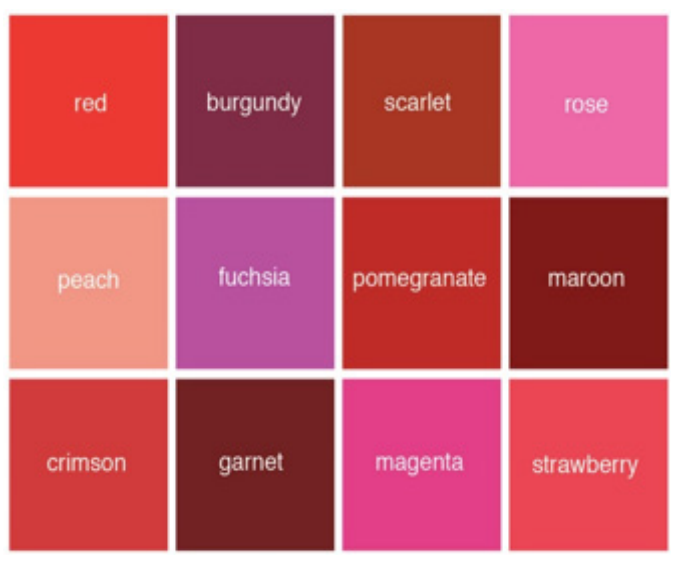

Figure 10 Example of Red Family Colors (Created by Purbasari, 2021)

For the Batak Toba society, the red color on the ulos fabric, which is also a family bonding in the dalih na tolu kinship system, has its own meaning based on the cosmos' concept middle world where there are humans and the universe. In the ulos fabric itself, red means courage and heroism (Rudiyanto, 2011). Besides, the red color is widely used in cultural masks in Indonesia. In Java, red masks generally symbolize something bad, jealousy, as well as rage or anger.

\section{CONCLUSIONS}

The warm color family such as yellow, orange, and red with a high level of information (color intensity) make these colors look striking, bold, strong, and attractive. Because of this power, the warm color family has two opposite sides of the character, depending on the context in which this color is used. The character of strong warm colors is better to use to be accompanied by or balanced with cool colors or to play with the tint-tone-shade, according to its purpose because warm colors tend to have high intensity so that they quickly tire the eyes.

Knowing the character of color becomes important when color is used primarily as a communication tool. As a color user, it must be sensitive to the character, function, purpose, and target of the color so that the strength of the color can be maximized. The research certainly requires further steps. There are still many colorful characters that can be explored, for example, neutral colors, such as black, white, and gray. In fact, it does not rule out the research of color characters in terms of tint-toneshade.

\section{REFERENCES}

Danesi, M. (2004). Messages, signs, and meanings: A basic textbook in Semiotics and Communication Theory $\left(3^{\text {rd }}\right.$ Ed). Toronto: Canadian Scholars' Press Inc. 
Elliot, A. J. (2015). Color and psychological functioning: a review of theoretical and empirical work. Frontiers in Psychology, 6, 1-8. https://doi.org/10.3389/ fpsyg.2015.00368

Green-Armytage, P. (2017). More than colour - dimensions of light and appearance. Journal of the International Colour Association, 17, 1-27.

Hoed, B. H. (2011). Semiotik dan dinamika sosial budaya. Depok: Komunitas Bambu.

Kumar, R. (2016). A note on colour psychology of Indian and Chinese culture and possible impact on advertising. In India China and The New World Order. Odisha, India. pp. 1-10.

Kuniecki, M., Pilarczyk, J., \& Wichary, S. (2015). The color red attracts attention in an emotional context: An ERP study. Frontiers in Human Neuroscience, 9, 1-14. https://doi.org/10.3389/fnhum.2015.00212.

Lampu Edison. (2020). Arti warna menurut berbagai budaya di Indonesia (Bagian 1). Retrieved from https://kumparan.com/lampu-edison/arti-warnamenurut-berbagai-budaya-di-indonesia-bagian-11 toanv $7601 \mathrm{c} /$ full.

Leo. (2019). Tiga ciri dan makna desain seragam bank yang ada di Indonesia. Retrieved from http:// craiovaonline.com/fashion/3-ciri-dan-maknadesain-seragam-bank-yang-ada-di-indonesia/.

Morton, J. L. (2021a). Orange - The meanings of orange. Retrieved from https:/www.colormatters.com/ color-and-marketing/59-color-symbolism/themeanings-of-colors\#.

Morton, J. L. (2021b). Red - The meanings of red. Retrieved from https://www.colormatters.com/the-meaningsof-colors/red.

Pettersson, R. (1982). Cultural differences in the perception of image and color in pictures. Educational Communication and Technology, 30(1), 41-53. https://doi.org/10.1007/BF02766547.

Piqueras-Fiszman, B., \& Spence, C. (2014). Colour, pleasantness, and consumption behaviour within a meal. Appetite, 75, 165-172. https://doi. org/10.1016/j.appet.2014.01.004.

Purbasari, M., \& Jakti, D. R. (2011). Khazana warna berdasarkan hasana alam dan budaya nusantara (1). Humaniora, 2(1), 722-730. https://doi.org/10.21512/ humaniora.v2i1.3089.
Purbasari, M., \& Jakti, D. R. (2014). Warna dingin si pemberi nyaman. Humaniora, 5(1), 357-366. https:// doi.org/10.21512/humaniora.v5i1.3034.

Purbasari, M., Marianto, M. D., \& Burhan, M. A. (2016). The dynamic of Betawi in colors. Mudra, 31(3), 384-392. https://doi.org/10.31091/mudra.v31i3.59.

Rossi, M., Rizzi, A., Bonanomi, C., \& Siniscalco, A. (2018). Color: An experiential path between theory and practice. Journal of the International Colour Association, 22, 34-40.

Rudiyanto, G. (2011). Periodisasi pola-pola perubahan pada tenun ulos Batak Toba di Sumatera Utara dan tenun gringsing di Tenganan Bali dari abad ke-19 sampai abad ke-20. Dimensi, 8(2), 63-77. http://dx.doi. org/10.25105/dim.v8i2.

Scoot, D. (2018). Color and light-What is color temperature. Retrieved from https://drawpaintacademy.com/ what-is-color-temperature/.

Sevinc, K., \& Osueke, K. K. (2014). The effects of color on the moods of college students. Sage Open, 4(1), 1-12. https://doi.org/10.1177/2158244014525423.

Smith, K. (2019a). Color symbolism and meaning of orange. Retrieved on January 9, 2021 from https:// www.sensationalcolor.com/meaning-of-orange/.

Smith, K. (2019b). Color symbolism and meaning of yellow. Retrieved on January 9, 2021 from https://www. sensationalcolor.com/meaning-of-yellow/.

Wahidiyat, M. P., \& Tabroni, I. (2020). Color game on ondel-ondel as cultural education media for children. Capture, 12(1), 87-95. https://doi.org/10.33153/ capture.v12i1.3263.

Widyaningrum, G. L. (2019). Dari India hingga Afrika, ini makna warna di beberapa negara dunia. Retrieved on https://nationalgeographic.grid.id/ $\mathrm{read} / 131665120 /$ dari-india-hingga-afrika-inimakna-warna-di-beberapa-negara-dunia?page=all.

Woelandhary, A. D. (2019). Unsur rupa dan makna pada busana pengantin Betawi. Jurnal Budaya Nusantara, 3(1), 1-11. https://doi.org/10.36456/b.nusantara. vol3.no1.a2109. 